Moderasi Jurnal Studi Ilmu Pengetahuan Sosial, Volume 2, No. 2, h. I6-28

\title{
IMPLEMENTASI KEBIJAKAN SERTIFIKASI GURU DALAM MENINGKATKAN MUTU PEMBELAJARAN DI SMA NEGERI 1 DOLO KABUPATEN SIGI
}

\author{
Rizka Fadliah Nur \\ Dosen Tadris IPS, Fakultas Tarbiyah dan Ilmu Keguruan, UIN Datokarama Palu \\ E-mail: rizka_fadliahNur@iainpalu.ac.id \\ Taufiq Eka Riandhana \\ Dosen PKn, Fakultas Peternakan dan Perikanan, Universitas Tadulako Palu \\ Email: taufiqekariandhana168@gmail.com
}

\begin{abstract}
The purpose of the study was to determine the implementation of teacher certification policies in improving the quality of learning in SMA Negeri 1 Dolo and the inhibiting, supporting factors and alternative solutions. The basis of the research is a survey, and the type of research is descriptive qualitative which is intended to provide a general description of the object under study. In this study, the authors set the Dolo 1 State High School as the research location. The population in this study was 646 (six hundred and forty-six) people. Sampling using the purposive sampling technique, as many as 35 people, consisting of Deputy Principals, Teachers, School Committees, Administration and Students. Data collection techniques through observation, interviews, questionnaires, and documentation. This study uses a qualitative descriptive analysis technique and the results of this study will be presented using tools in the form of frequency tables and percentage tables. The results of this study indicate that communication, bureaucratic structure that causes good input and output to produce quality students in the sense of having adequate skills and knowledge after graduating from State High School 1 Dolo and being able to compete with other schools to enter higher education. . However, resources and dispositions that affect the learning process. In this case, the attitude, nature, or characteristics of the teacher are not good in terms of obedience and accuracy of entry at the time of teaching so that the quality of learning is of less quality due to the hours of learning that are not by the specified.
\end{abstract}

Keyword : Policy Implementation, Teacher Certification

\begin{abstract}
Abstrak
Tujuan penelitian yaitu untuk mengetahui Implementasi Kebijakan Sertifikasi Guru Dalam Meningkatkan Mutu Pembelajaran di SMA Negeri 1 Dolo dan faktor penghambat, pendukung serta alternatif pemecahannya. Dasar penelitian adalah survei, dan jenis penelitian adalah deskriptif kualitatif yang dimaksudkan untuk memberikan gambaran secara umum tentang obyek yang diteliti. Dalam penelitian ini penulis menetapkan Sekolah Menengah Atas Negeri 1 Dolo sebagai lokasi penelitian. Populasi dalam penelitian ini adalah sebanyak 646 (enam ratus empat puluh enam) orang. Penarikan sampel dengan tekhnik Purposive Sampling, yaitu sebanyak 35 orang, terdiri dari Wakil Kepala Sekolah, Guru, Komite Sekolah, Tata Usaha dan Peserta didik. Tekhnik pengumpulan data melalui observasi, wawancara, kuesioner dan dokumentasi. Penelitian ini menggunakan tekhnik analisis deskriptif kualitatif dan hasil penelitian ini akan dipresentasekan dengan menggunakan alat bantu berupa tabel frekuensi dan tabel presentase. Hasil penelitian ini menunjukan bahwa komunikasi, struktur birokrasi yang menyebabkan Input dan output yang baik sehingga menghasilkan peserta didik yang berkualitas dalam artian memiliki
\end{abstract}


keterampilan dan pengetahuan yang memadai setelah lulus dari Sekolah Menengah Atas Negeri 1 Dolo dan mampu bersaing dengan sekolah lain untuk masuk ke perguruan tinggi. Akan tetapi, sumber daya dan disposisi yang berpengaruh pada proses pembelajaran. Dalam hal ini sikap, sifat atau karakteristik guru yang kurang baik dalam hal ketaatan dan ketepatan masuk pada saat mengajar sehingga mengakibatkan mutu pembelajaran kurang berkualitas yang disebabkan jam masuk belajar yang tidak sesuai dengan yang ditentukan.

Kata Kunci : Implementasi Kebijakan, Sertifikasi Guru

\section{Pendahuluan}

Pendidikan merupakan hal terpenting dalam kehidupan, ini berarti bahwa setiap manusia berhak mendapat dan berharap untuk selalu berkembang dalam pendidikan. Pendidikan secara umum mempunyai arti suatu proses kehidupan dalam mengembangkan diri tiap individu untuk dapat hidup dan melangsungkan kehidupan, sehingga menjadi seorang yang terdidik itu sangat penting. Pendidikan pertama kali yang kita dapatkan di lingkungan keluarga, lingkungan sekolah dan lingkungan masyarakat. Masalah pendidikan menjadi salah satu faktor penting dalam kebijakan guru selaku pendidik mempunyai tugas dan tanggung jawab terhadap masalah pendidikan di negaranya masing-masing, di Indonesia masalah pendidikan masih menjadi faktor utama tertinggalnya prestasi dan kualitas sumber daya manusia, sehingga dalam upaya peningkatan mutu pendidikan dan prestasi anak bangsa masih minim.

Sebagai tenaga profesional, guru diharapkan dapat berfungsi untuk meningkatkan martabat dan peran guru sebagai agen pembelajaran dan berfungsi untuk meningkatkan mutu pendidikan nasional dalam proses pembelajaran. Agar terciptanya kesejahteraan guru dalam upaya untuk meningkatkan kualitas pembelajaran, maka Menteri Pendidikan Nasional mengeluarkan peraturan Nomor 18 Tahun 2007 tentang sertifikasi bagi guru yang diharapkan agar guru dapat memberikan dan mengupayakan peserta didiknya dapat belajar lebih giat dan tekun.

Peranan dan kedudukan guru dalam meningkatkan mutu dan kualitas peserta didik perlu diperhitungkan dengan sungguh-sungguh, status guru bukan hanya sebatas pegawai yang hanya semata-mata melaksanakan tugas tanpa ada rasa tanggung jawab terhadap disiplin ilmu yang diembannya. Jadi, dapat disimpulkan bahwa sertifikasi guru dalam bidang profesi kependidikan adalah proses pemberian sertifikat kepada guru untuk meningkatkan kualitas guru sebagai pendidik dalam segala aspek yang diajarkan oleh guru kepada peserta didik yang dididiknya atas bidang profesinya dalam kependidikan. Sertifikasi guru merupakan sebuah terobosan dalam dunia pendidikan untuk meningkatkan kualitas dan profesionalitas seorang guru, sehingga ke depan semua guru harus memiliki sertifikat sebagai lisensi atau ijin mengajar. Dengan demikian, upaya pembentukan guru yang profesional di Indonesia segera menjadi kenyataan dan diharapkan tidak semua orang dapat menjadi guru dan tidak semua orang menjadikan profesi guru sebagai batu loncatan untuk memperoleh pekerjaan seperti yang terjadi belakangan ini.

Berdasarkan uraian di atas, sertifikasi guru selain untuk meningkatkan kualitas guru sebagai pendidik dalam segala aspek juga dapat menunjang dan mempengaruhi mutu pembelajaran. Harus diakui bahwa berbicara mengenai mutu pembelajaran tidak lepas dari kebijakan atau peran seorang guru yang telah tersertifikasi, dimana mutu pembelajaran dapat ditingkatkan sesuai dengan keahlian dan kemampuan guru tersebut. 
Berdasarkan hasil observasi awal ditemukan masalah yang cukup signifikan yaitu guru yang telah tersertifikasi tidak memiliki tanggungjawab penuh atas apa yang diembannya contohnya yaitu pada saat jam pelajaran, tenaga pendidik tersebut tidak masuk atau memiliki alasan lain di luar sekolah. Sebagai seorang tenaga pendidik yang baik, seharusnya mendahulukan kewajibannya sebagai pendidik, karena itu akan berpengaruh terhadap mutu pembelajaran dan proses belajar mengajar. Apabila tenaga pendidik bersikap profesional maka dapat dirasakan dampak atau output dari peserta didik, yang dilihat dari prestasi peserta didik dalam hal prestasi akademik yang berupa nilai dan non akademik misalnya IMTAQ. Paradigma mutu dalam dunia pendidikan tentunya tidak lepas dari proses pembelajaran dan dari input pendidikan yang diajarkan oleh tenaga pendidik karena proses dan input dalam dunia pendidikan memiliki keterkaitan dimana segala sesuatu yang tersedia dalam proses pembelajaran seperti sumberdaya manusia dan berbagai sarana prasarana lainnya merupakan bagian dari proses pembelajaran.

Dalam penelitian ini penetapan sasaran kajian yang dilakukan mengarah kepada sertifikasi guru, dimana sertifikasi ini bermanfaat bagi guru untuk meningkatkan mutu pembelajaran. Oleh karena itu, judul yang diangkat pada penelitian ini yaitu "Implementasi Kebijakan Sertifikasi Guru Dalam Meningkatkan Mutu Pembelajaran di SMA Negeri 1 Dolo Kabupaten Sigi". Berdasarkan uraian pada latar belakang masalah, maka dapat dirumuskan permasalahan penelitian yaitu Bagaimana Implementasi Kebijakan Sertifikasi Guru Dalam Meningkatkan Mutu Pembelajaran di SMA Negeri 1 Dolo Kabupaten Sigi? Dan Faktor apa yang menjadi penghambat serta pendukung serta alternatif pemecahannya?

Tujuan Penelitian yaitu untuk mengetahui Implementasi Kebijakan Sertifikasi Guru Dalam Meningkatkan Mutu Pembelajaran di SMA Negeri 1 Dolo Kabupaten Sigi dan untuk mengetahui faktor yang menjadi penghambat dan penunjang serta alternatif pemecahannya. Manfaat Penelitian yaitu Hasil penelitian ini diharapkan dapat bermanfaat baik secara teoritis maupun secara praktis dari segi keilmuan, hasil penelitian dapat bermanfaat bagi pengembangan pengetahuan khususnya mengenai Implementasi Kebijakan Sertifikasi Guru Terhadap Mutu Pembelajaran di SMA Negeri 1 Dolo Kabupaten Sigi dan dari Segi terapan, diharapkan dapat menjadi bahan pertimbangan bagi SMA Negeri 1 Dolo Kabupaten Sigi agar dapat meningkatkan Mutu Pembelajaran dan output dari SMA Negeri 1 Dolo memiliki kualitas yang baik.

\section{Metode Penelitian}

Dasar Penelitian ini dilakukan dengan menggunakan metode penelitian survei yaitu penelitian yang mengambil sampel dari satu populasi dan menggunakan kuesioner sebagai alat pengumpul data yang pokok ${ }^{1}$. Whitney menyatakan bahwa metode deskriptif ini merupakan pencarian fakta dengan interpretasi yang tepat ${ }^{2}$. Dimana penelitian ini bertujuan untuk memberikan gambaran secara transparan tentang implementasi kebijakan sertifikasi guru yang berkaitan dengan kualitas kelulusan peserta didik. Sesuai dengan judul yang diambil maka yang menjadi lokasi penelitian yaitu Sekolah Menengah Atas Negeri 1 Dolo Kabupaten Sigi.

Populasi adalah wilayah generalisasi yang terdiri atas obyek/subyek yang mempunyai kuantitas dan karakteristik tertentu yang ditetapkan oleh peneliti untuk

1 Singarimbun Masrin dan Sofian Effendi. 2006. Metode penelitian survai (Revisi). (LP3ES: Jakarta). 3

${ }^{2}$ Nazir, Moh. 2003. Metode Penelitian. (Ghalia Indonesia: Jakarta). 63 
dipelajari dan kemudian ditarik kesimpulannya ${ }^{3}$. Adapun yang menjadi populasi dalam penelitian ini adalah Seluruh civitas akademik SMA Negeri 1 Dolo Kabupaten Sigi yang berjumlah 646 Orang. Sampel sering didefinisikan sebagai bagian dari populasi, sebagai contoh (master) yang diambil dengan menggunakan cara-cara tertentu. Maka penarikan sampel yang digunakan yaitu dengan cara purposive sampling yaitu tekhnik penentuan sampel dengan pertimbangan khusus sehingga layak dijadikan sampel. Oleh karena itu, sampel pada penelitian ini yaitu sebanyak 35 orang dari 646 jumlah keseluruhan civitas akademik SMA Negeri 1 Dolo Kabupaten Sigi.

Tekhnik pengumpulan data yaitu melalui Pengamatan (Observasi), Wawancara, kuesioner atau angket, dan studi dokumen. Sesuai judulnya, penelitian ini memiliki 2 (dua) variabel yaitu variabel dependen dan independen. Variabel independen membahas Implementasi Kebijakan dengan indikator Komunikasi, Sumber Daya, Disposisi, dan Struktur Birokrasi. Sedangkan variabel dependen membahas tentang mutu pembelajaran dengan indikator input proses dan output. Dalam hal implementasi kebijakan, sertifikasi guru dipandang sebagai salah satu cara yang jitu untuk meningkatkan hal tersebut dan dapat terlaksana sesuai dengan prosedur dan standar yang telah ditetapkan sehingga untuk mempermudah penelitian ini, maka kontribusi teori yang digunakan yaitu teori menurut Edward III bahwa masalah utama dari administrasi publik adalah komunikasi yang berkenaan dengan bagaimana kebijakan dikomunikasikan kepada organisasi dan/atau publik, ketersediaan sumber daya untuk melaksanakan kebijakan, sikap, dan tanggapan dari para pihak yang terlibat dan bagaimana struktur organisasi pelaksanaan kebijakan. Oleh sebab itu, menurut Edward III ada empat faktor atau variabel yang dapat digunakan untuk mengkaji sebuah kebijakan yaitu ${ }^{4}$ :

1. Komunikasi, keberhasilan kebijakan mensyaratkan agar implementor mengetahui apa yang harus dilakukan. Apa yang menjadi tujuan dan sasaran kebijakan (target group) sehingga akan mengurangi distorsi implementasi. Apabila tujuan dan sasaran suatu kebijakan tidak jelas atau bahkan tidak diketahui sama sekali oleh kelompok sasaran, maka kemungkinan akan terjadi resistensi dari kelompok sasaran.

2. Sumber daya, walaupun isi kebijakan sudah dikomunikasikan secara jelas dan konsistensi, tetapi apabila implementor kekurangan sumber daya untuk melaksanakan, implementasi tidak akan berjalan efektif. Sumber daya tersebut dapat berwujud sumber daya manusia, yakni kompetisi implementor, dan sumber daya financial. Sumber daya adalah faktor penting untuk implementasi kebijakan agar efektif. Tanpa sumber daya, kebijakan hanya tinggal di kertas menjadi dokumen saja.

3. Disposisi, adalah watak dan karakteristik atau sikap yang dimiliki oleh implementor seperti komitmen, kejujuran, sifat demokratis. Apabila implementor memiliki disposisi yang baik, maka dia akan dapat menjalankan kebijakan dengan baik seperti apa yang diinginkan oleh pembuat kebijakan. Ketika implementor memiliki sifat atau perspektif yang berbeda dengan pembuat kebijakan, maka proses implementasi kebijakan juga menjadi tidak efektif.

4. Struktur birokrasi yang bertugas mengimplementasikan kebijakan memiliki pengaruh yang signifikan terhadap implementasi kebijakan. Salah satu dari aspek struktur yang penting dari setiap organisasi adalah adanya prosedur operasi yang standar (standard operating procedures) atau SOP. SOP menjadi pedoman bagi setiap implementor dalam bertindak. Struktur organisasi yang terlalu panjang akan

\footnotetext{
${ }^{3}$ Sugiyono. 2001. Statistik nonparametris untuk penelitian. (Alfabeta: Bandung). 5

${ }^{4}$ Juliartha. 2009. Model Implementasi Kebijakan Publik. (Trio Rimba Persada: Jakarta). 58
} 
cenderung melemahkan pengawasan dan menimbulkan red tape, yakni prosedur birokrasi yang rumit dan kompleks. Ini pada gilirannya menyebabkan aktivitas organisasi tidak fleksibel.

Berdasarkan pemilihan parameter tersebut sehingga dapat dilihat dampaknya pada distribusi sertifikasi guru apakah membantu dalam meningkatkan mutu pembelajaran atau tidak, dengan menilai dari parameter Input pendidikan yang merupakan segala sesuatu yang harus tersedia karena dibutuhkan untuk berlangsungnya proses. Sesuatu yang dimaksud berupa sumber daya dan perangkat lunak serta harapan-harapan sebagai pemandu bagi berlangsungnya proses. Input sumber daya meliputi sumber daya manusia (kepala sekolah, guru termasuk guru BP, staf dan peserta didik) dan sumber daya selebihnya (peralatan, perlengkapan, uang, bahan dan sebagainya). Input perangkat lunak meliputi struktur organisasi sekolah, peraturan perundang-undangan, deskripsi tugas, rencana dan program. Input harapan-harapan berupa visi, misi, tujuan dan sasaran-sasaran yang ingin dicapai oleh sekolah. Kesiapan input sangat diperlukan agar proses dapat berlangsung dengan baik. Oleh karean itu rendahnya mutu input dapat diukur dari tingkat kesiapan input. Makin tinggi tingkat kesiapan input, makin tinggi pula mutu input tersebut.

Proses pendidikan merupakan berubahnya sesuatu hal menjadi sesuatu yang lain. Sesuatu yang berpengaruh terhadap berlangsungnya proses tersebut disebut input, sedang hasil dari proses disebut output. Dalam pendidikan berskala mikro (sekolah), proses yang dimaksud adalah proses pengambilan keputusan, proses pengelolaan kelembagaan, proses pengelolaan program, proses belajar mengajar, dan proses monitoring dan evaluasi, dengan catatan bahwa proses belajar mengajar memiliki tingkat kepentingan tertinggi dibandingkan dengan proses-proses lainnya. Proses dikatakan bermutu tinggi apabila pengkoordinasian dan penyerasian serta pemaduan input sekolah (guru, peserta didik, kurikulum, uang, peralatan, dan sebagainya) dilakukan secara harmonis, sehingga mampu menciptakan situasi pembelajaran yang menyenangkan (enjoyable learning), mampu mendorong motivasi dan minat belajar dan benar-benar mampu memberdayakan peserta didik. Kata memberdayakan mengandung arti bahwa peserta didik tidak sekedar menguasai pengetahuan yang diajarkan oleh gurunya, tetapi pengetahuan tersebut juga telah menjadi muatan nurani peserta didik, dihayati, diamalkan dalam kehidupan seharihari dan yang lebih penting lagi peserta didik tersebut mampu belajar cara belajar (mampu mengembangkan dirinya).

Output pendidikan adalah merupakan kinerja sekolah. Kinerja sekolah adalah prestasi sekolah yang dihasilkan dari proses/perilaku sekolah. Kinerja sekolah dapat diukur dari kualitasnya, efektivitasnya, produktivitasnya, efesiensinya, inovasinya, kualitas kehidupan kerjanya dan moral kerjanya. Khusus yang berkaitan dengan mutu output sekolah, dapat dijelaskan bahwa output sekolah dikatakan berkualitas atau bermutu tinggi jika prestasi sekolah, khususnya prestasi peserta didik, menunjukan pencapaian yang tinggi dalam: (1) prestasi akademik, berupa nilai ulangan umum, nilai ujian akhir, karya ilmiah, lomba-lomba akademik; dan (2) prestasi non-akademik, seperti misalnya IMTAQ, kejujuran, kesopanan, olahraga, kesenian, keterampilan dan kegiatan-kegiatan ekstrakurikuler lainnya. Mutu sekolah dipengaruhi oleh banyak tahapan kegiatan yang saling berhubungan (proses) seperti misalnya perencanaaan, pelaksanan, dan pengawasan. Hasil pendidikan dipandang bermutu jika mampu melahirkan keunggulan akademik dan ekstrakurikuler pada peserta didik yang dinyatakan lulus dari suatu jenjang pendidikan tertentu. Keunggulan akademik dinyatakan dengan nilai yang dicapai peserta didik. Keunggulan ekstrakurikuler dinyatakan dengan aneka jenis keterampilan yang diperolah peserta didik selama 
mengikuti program ekstrakurikuler ${ }^{5}$. Oleh karena itu dapat dilihat pada kerangka pikir berikut :

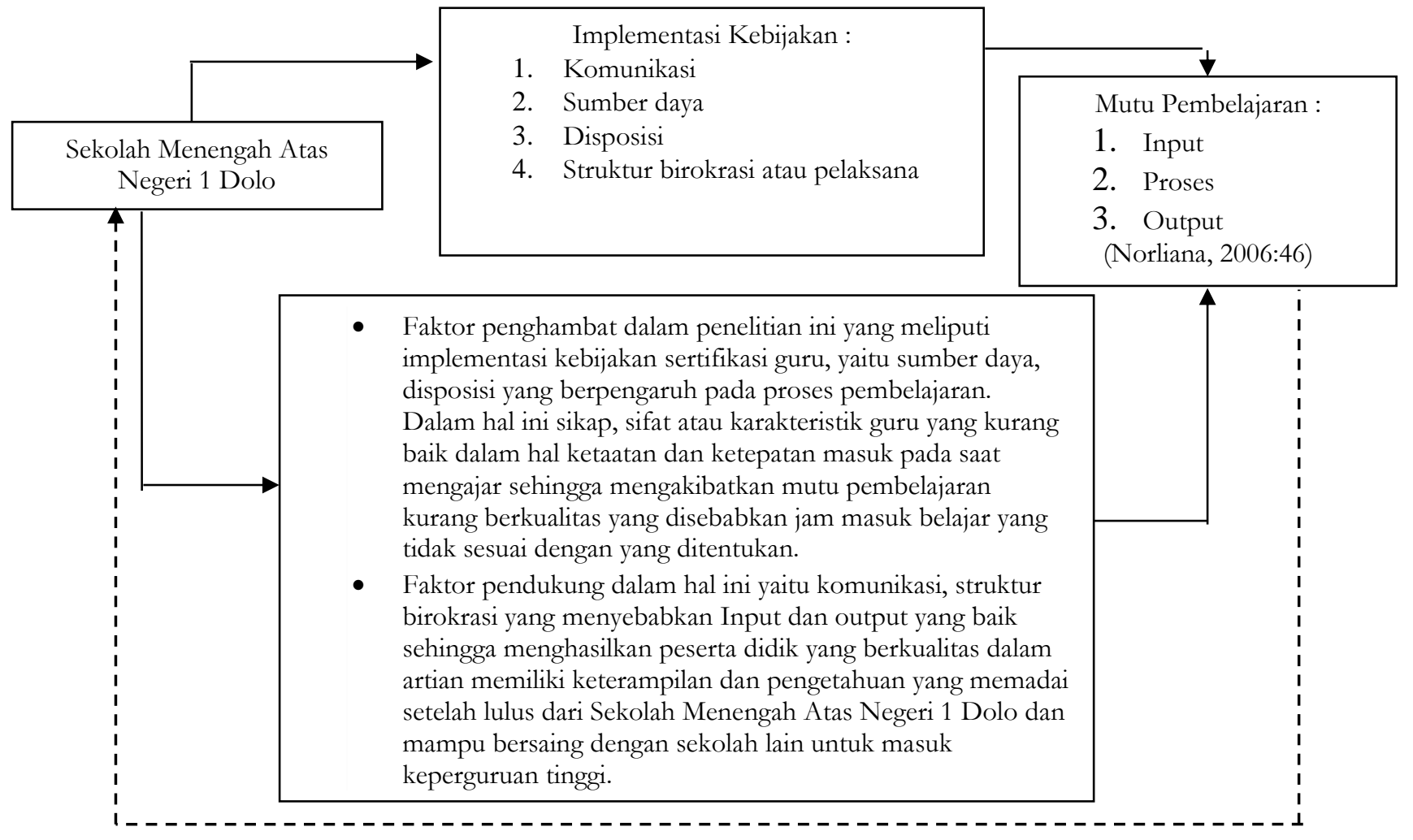

\section{Hasil Dan Pembahasan}

Struktur Organisasi SMA Negeri 1 Dolo yang merupakan suatu sistem Manajemen organisasi Sekolah yang diatur berdasarkan fungsi, tugas dan tanggungjawab masing-masing personil dalam rangka mencapai tujuan akhir pendidikan yang telah ditetapkan sebelumnya. Struktur Organisasi SMA Negeri 1 Dolo diatur berdasarkan Fungsi sebagai berikut :

a. Kepala Sekolah adalah Pimpinan tertinggi sekaligus pengambil kebijakan dalam Manajemen organisasi pada SMA Negeri 1 Dolo, demi terciptanya suasana pembelajaran yang tertib dan menyenangkan.

b. Sekertaris selaku pemegang kendali administrasi dan Manajemen kependidikan secara umum, memiliki wewenang dan tanggungjawab terhadap pengendalian mutu dan tata kearsipan seluruh kebijakan Administrasi kependidikan.

c. Wakil Kepala Sekolah selaku pembantu Kepala Sekolah sesuai bidang masingmasing, memiliki wewenang dan Tanggungjawab, sekaligus dapat mewakili Kepala Sekolah didalam maupun diluar Sekolah bila Kepala Sekolah berhalangan atau keluar daerah atau tidak berada ditempat.

d. Koordinator Bimbingan Konseling memiliki tugas dan tanggungjawab dalam mengelola lingkungan sekolah sehingga tercipta suasana lingkungan yang ASRI (Aman, Santun, Rindang dan Indah) serta penuh kekeluargaan.

Berdasarkan hasil penelitian yang dilaksanakan di Sekolah Menengah Atas Negeri 1 Dolo mengenai implementasi kebijakan sertifikasi terhadap mutu pembelajaran peserta didik didapatkan hasil bahwa setiap tenaga pendidik yaitu guru

5 Norliana. 2006. Risk Assessment Process of Hazards in Construction Sites. (Faculty of Civil Engineering: University Teknologi Malaysia). 46 
yang telah tersertifikasi memiliki caranya masing-masing dalam meningkatkan kualitas setiap peserta didik. Oleh sebab itu, sertifikasi yang telah dilaksanakan pemerintah memiliki dampak yang sangat besar bagi seorang guru. Sehubungan dengan topik penelitian dan berdasarkan parameter-parameter yang telah ditentukan sebelumnnya sebagai bahan dasar kajian penelitian di lapangan, maka dapat diuraikan sebagai berikut :

1. Komunikasi

komunikasi merupakan suatu proses pemberian informasi. Apabila tidak ada komunikasi yang baik dalam suatu pekerjaan maka akan menghasilkan sesuatu yang tidak maksimal, hal ini sama seperti komunikasi yang terjalin antara tenaga pendidik di SMA Negeri 1 Dolo Kabupaten Sigi. Guru di SMA Negeri 1 Dolo Kabupaten Sigi memiliki cara sendiri dalam menyampaikan suatu materi pelajaran kepada peserta didiknya pada saat proses belajar mengajar agar lebih mudah dipahami oleh peserta didik. Oleh karena itu, untuk mengetahui komunikasi yang terjalin antara guru dan peserta didik pada proses pembelajaran berlangsung maka dapat dilihat pada tabel frekuensi dan presentasi yang memperlihatkan terdapat 18 responden atau 51,42 persen mengatakan bahwa komunikasi yang terjalin antara guru dan peserta didik sudah baik, 10 responden atau 28,57 persen mengatakan sangat baik, 5 responden atau 14,28 persen mengatakan kurang baik dan 2 responden atau 5,71 persen mengatakan kerjasama komunikasi yang terjalin tidak baik. Berdasarkan tanggapan responden mengenai komunikasi yang dilakukan antara seorang guru pada proses pembelajaran, dapat dikatakan dalam kategori baik.

TABEL 1

Tanggapan Responden Tentang Komunikasi

Antara Seorang Guru dan Peserta didik Pada Proses Pembelajaran

\begin{tabular}{|c|l|c|c|}
\hline NO & \multicolumn{1}{|c|}{ Tanggapan Responden } & Frekuensi & Presentasi (\%) \\
\hline \hline 1 & Sangat Baik & 10 & 28,57 \\
\hline \hline 2 & Baik & 18 & 51,42 \\
\hline \hline 3 & Kurang Baik & 5 & 14,28 \\
\hline \hline 4 & Tidak Baik & 2 & 5,71 \\
\hline \multicolumn{2}{|r|}{ JUMLAH } & 35 & 100,00 \\
\hline
\end{tabular}

\section{Sumber daya}

Sumber daya merupakan suatu paramater yang penting karena mengukur kualitas individu yaitu guru dan peserta didik, dimana seorang guru yang telah tersertifikasi memiliki kemampuan yang baik sehingga dampaknya dapat memberikan pemahaman serta penyampaian kepada peserta didik dengan mudah. Untuk mengetahui tanggapan responden yang berkaitan dengan sumber daya yaitu mengukur kualitas guru dan peserta didik maka dapat dilihat pada tabel frekuensi dan presentasi yang menunjukan terdapat 7 responden atau 20,00 persen mengatakan bahwa sumber daya yang ada di SMA Negeri 1 Dolo tidak baik, 15 responden atau 42,85 persen mengatakan kurang baik, 10 responden atau 28,57 persen mengatakan sudah baik dan 3 responden atau 8,57 persen mengatakan sumber daya yang ada sudah sangat baik. Tanggapan respoden menunjukan bahwa sumber daya yang ada di SMA Negeri 1 Dolo kurang baik dalam hal ini lebih menyorot kepada tenaga pendidik yaitu guru. Namun jika dilihat dari rasio tabel frekuensi, hanya sekitar 5 orang yang menjadi pembeda apakah kualitas dari seorang peserta didik dan guru sudah baik atau belum. 
TABEL 2

Tanggapan Responden Tentang

Kualitas Sorang Guru Yang Telah Tersertifikasi

Dalam Meningkatkan Mutu Pembelajaran

\begin{tabular}{|c|l||c||c|}
\hline \hline NO & \multicolumn{1}{|c||}{ Tanggapan Responden } & Frekuensi & Presentasi (\%) \\
\hline \hline 1 & Sangat Baik & 3 & 8,57 \\
\hline 2 & Baik & 10 & 28,57 \\
\hline \hline 3 & Kurang Baik & 15 & 42,85 \\
\hline 4 & Tidak Baik & 7 & 20,00 \\
\hline \hline \multicolumn{2}{|r|}{ JUMLAH } & 35 & 100,00 \\
\hline \hline
\end{tabular}

\section{Disposisi}

Pada parameter ini disposisi merupakan watak dan karakteristik atau sikap yang dimiliki oleh implementor seperti komitmen, kejujuran, sifat demokratis. Apabila implementor memiliki disposisi yang baik, maka dia akan dapat menjalankan kebijakan dengan baik seperti apa yang diinginkan oleh pembuat kebijakan, dalam hal ini pemerintah yang mencanangkan program sertifikasi guru. Untuk mengetahui apakah karakeristik dari tenaga pendidik/guru yang telah tersertifikasi dapat berpengaruh atau tidak di Sekolah Menengah Atas Negeri 1 Dolo, maka kita lihat pada tabel frekuensi dan presentasi yang memperlihatkan 12 responden atau 34,28 persen mengatakan sangat baik, 6 responden atau 17,14 persen mengatakan bahwa karakteristik kerja guru yang tersertifikasi dalam meningkatkan tingkat kelulusan sudah baik, 13 responden atau 37,14 persen mengatakan kurang baik dan 4 responden atau 11,42 persen mengatakan karakteristik kerja guru yang telah tersertifikasi dalam meningkatkan kualitas kelulusan tidak baik.

TABEL 3

Tanggapan Responden Tentang

Karakteristik Kerja Guru Yang Tersertifikasi

Dalam Meningkatkan Mutu Pembelajaran

\begin{tabular}{|c||l||c|c|}
\hline NO & \multicolumn{1}{|c|}{ Tanggapan Responden } & Frekuensi & Presentasi (\%) \\
\hline \hline 1 & Sangat Baik & 12 & 34,28 \\
\hline 2 & Baik & 6 & 17,14 \\
\hline 3 & Kurang Baik & 13 & 37,14 \\
\hline 4 & Tidak Baik & 4 & 11,42 \\
\hline \multicolumn{2}{|c|}{ JUMLAH } & 35 & 100,00 \\
\hline
\end{tabular}

4. Struktur birokrasi atau pelaksanaan

Struktur Birokrasi atau pelaksanaan merupakan suatu parameter yang cukup berpengaruh terhadap implementasi dari sebuah kebijakan, dalam hal ini yaitu sertifikasi guru. Oleh karena itu, untuk menentukan apakah sertifikasi ini sangat berpengaruh terhadap peningkatan mutu pembelajaran Sekolah Menengah Atas Negeri 1 Dolo atau tidak, dapat kita lihat pada tabel frekuensi dan presentasi yang memperlihatkan terdapat 8 responden atau 22,85 persen mengatakan sangat baik, 23 responden atau 65,71 persen mengatakan bahwa pelaksanaan kerja guru yang tersertifikasi pada proses belajar mengajar sudah masuk kategori baik, 3 responden atau 8,57 persen mengatakan kurang baik dan 1 responden atau 2,85 persen mengatakan pelaksanaan kerja guru yang tersertifikasi tidak baik. Tanggapan responden menunjukan bahwa dalam pelaksanaan proses belajar mengajar di Sekolah menengah Atas Negeri 1 Dolo sudah masuk kategori baik. 
TABEL 4

Tanggapan Responden Tentang

Pelaksanaan Kinerja Guru Yang Tersertifikasi Pada Proses Belajar Mengajar

\begin{tabular}{|c|l||c||c|}
\hline NO & \multicolumn{1}{|c||}{ Tanggapan Responden } & Frekuensi & Presentasi (\%) \\
\hline \hline 1 & Sangat Baik & 8 & 22,85 \\
\hline 2 & Baik & 23 & 65,71 \\
\hline 3 & Kurang Baik & 3 & 8,57 \\
\hline 4 & Tidak Baik & 1 & 2.85 \\
\hline \hline \multicolumn{2}{|r|}{ JUMLAH } & 35 & 100,00 \\
\hline
\end{tabular}

\section{Input}

Pelaksanaan program sertifikasi guru selain untuk meningkatkan kualitas guru sebagai pendidik dalam segala aspek juga dapat menunjang dan mempengaruhi tingkat kualitas kelulusan peserta didik. Sehingga visi, misi, tujuan dan sasaran-sasaran yang ingin dicapai oleh sekolah dapat tercapai. Maka dari itu untuk melihat apakah dalam pelaksanaannya sertifikasi guru ini dapat membantu untuk mencapai tujuan, sasaran dan visi misi, dapat kita lihat pada tabel frekuensi dan presentasi yang memperlihatkan terdapat 20 responden atau 57,14 persen mengatakan bahwa guru yang tersertifikasi sangat berpengaruh terhadap output sekolah, kemudian sebanyak 7 responden atau 20.00 responden mengatakan guru yang tersertifikasi berpengaruh terhadap output sekolah sementara 3 responden atau 8,57 persen mengatakan kurang berpengaruh dan 5 atau 14,28 guru yang tersertifikasi tidak berpengaruh terhadap output sekolah. Dari hasil wawancara mempertegas kembali, bahwa guru dapat berpengaruh terhadap output sekolah dari segi visi dan misi. Namun dalam hal ini guru yang telah tersertifikasi lebih dianggap mampu untuk mengembangkan output yang ditentukan sekolah dibandingkan guru yang belum tersertifikasi.

TABEL 5

Tanggapan Responden Tentang

Pengaruh Guru Yang Tersertifikasi Tehadap Input Sekolah

\begin{tabular}{|c|l||c|c|}
\hline \hline NO & \multicolumn{1}{|c|}{ Tanggapan Responden } & Frekuensi & Presentasi (\%) \\
\hline \hline 1 & Sangat Berpengaruh & 7 & 20,00 \\
\hline 2 & Berpengaruh & 20 & 57,14 \\
\hline \hline 3 & Kurang Berpengaruh & 3 & 8,57 \\
\hline \hline 4 & Tidak Berpengaruh & 5 & 14,28 \\
\hline \hline \multicolumn{2}{r|}{ JUMLAH } & 35 & 100,00 \\
\hline
\end{tabular}

\section{Proses}

Proses pendidikan merupakan berubahnya sesuatu hal menjadi sesuatu yang lain tentu saja dalam artian proses pembelajaran. Proses dianggap sebagai kemampuan dari setiap individu, selain pengetahuan dari sekolah peserta didik dan guru juga dapat belajar pada media elektronik atau lainnya. Pada parameter ini guru yang telah tersertifikasi tentu saja mempunyai kemampuan yang lebih dari guru yang belum tersertifikasi. Guru yang telah tersertifikasi dituntut untuk memberikan pengetahuan yang lebih kepada peserta didiknya baik itu dari segi pengetahuan maupun keterampilan dalam proses pembelajaran. Maka dari itu dapat dilihat pada tabel frekuensi yang menunjukan terdapat 14 responden atau 40,00 persen mengatakan bahwa guru yang tersertifikasi sangat berpengaruh terhadap kualitas pengetahuan peserta didik, 4 responden atau 11,42 persen mengatakan begitu berpengaruh, 16 responden atau 45,71 persen mengatakan kurang berpengaruh dan 
sebanyak 1 responden atau 2,85 persen mengatakan guru yang tersertifikasi tidak berpengaruh terhadap kualitas pengetahuan peserta didik. Dengan melihat hasil ini tentu saja kita dapat mengetahui bahwa program sertifikasi yang dilakukan oleh pemerintah sangat membantu, selain menghasilkan guru yang lebih berkualitas, peserta didik juga memiliki pengetahuan yang lebih baik dikarenakan dalam proses pembelajarannya guru menerapkan metode pembelajaran yang baik.

TABEL 6

Tanggapan Responden Tentang

Pengaruh guru yang telah tersertifikasi terhadap proses pembelajaran

\begin{tabular}{|c|l||c|c|}
\hline NO & \multicolumn{1}{|c||}{ Tanggapan Responden } & Frekuensi & Presentasi (\%) \\
\hline \hline 1 & Sangat Berpengaruh & 4 & 11,42 \\
\hline \hline 2 & Berpengaruh & 14 & 40,00 \\
\hline 3 & Kurang Berpengaruh & 16 & 45,71 \\
\hline 4 & Tidak Berpengaruh & 1 & 2,85 \\
\hline \hline \multicolumn{2}{|r|}{ JUMLAH } & 35 & 100,00 \\
\hline
\end{tabular}

\section{Output}

Output pendidikan merupakan kinerja sekolah. Kinerja sekolah adalah prestasi sekolah yang dihasilkan dari proses/perilaku sekolah. Kinerja sekolah dapat diukur dari kualitasnya. Pada parameter sebelumnya input dan proses, sedangkan output ini merupakan hasil dari apa yang telah dilaksanakan. Pada parameter ini guru memiliki peran penting dalam menghasilkan peserta didik yang kompeten dan sekolah yang memiliki keunggulan dari sekolah lainnya. Pada tabel frekuensi menunjukan terdapat 23 responden atau 65,71 persen mengatakan bahwa guru yang telah tersertifikasi sangat berpengaruh terhadap output peserta didik, 7 responden atau 20,00 persen mengatakan begitu berpengaruh, 3 responden atau 8,57 persen mengatakan kurang berpengaruh dan 2 responden atau 5,71 persen mengatakan guru yang telah tersertifikasi tidak berpengaruh terhadap kualitas output peserta didik. Berdasarkan tanggapan responden, dapat diketahui bahwa guru yang telah tersertifikasi sangat berpengaruh terhadap peningkatan kualitas peserta didik dan kualitas sekolah.

TABEL 7

Tanggapan Responden Tentang

Pengaruh guru yang telah tersertifikasi terhadap output sekolah

\begin{tabular}{|c|l||c||c|}
\hline \hline NO & \multicolumn{1}{|c||}{ Tanggapan Responden } & Frekuensi & Presentasi (\%) \\
\hline \hline 1 & Sangat Berpengaruh & 23 & 65,71 \\
\hline 2 & Berpengaruh & 7 & 20,00 \\
\hline 3 & Kurang Berpengaruh & 3 & 8,57 \\
\hline 4 & Tidak Berpengaruh & 2 & 5,71 \\
\hline \multicolumn{2}{|r||}{ JUMLAH } & 35 & 100,00 \\
\hline
\end{tabular}

Faktor Penghambat dan Pendukung dalam penelitian ini yang berkaitan dengan variabel penelitian yaitu Implementasi Kebijakan Sertifikasi Guru Terhadap Mutu Pembelajaran Peserta didik Pada Sekolah Menengah Atas Negeri 1 Dolo dijelaskan sebagai berikut:

1. Faktor penghambat dalam penelitian ini yang meliputi implementasi kebijakan sertifikasi guru, yaitu sumber daya, disposisi yang berpengaruh pada proses pembelajaran. Dalam hal ini sikap, sifat atau karakteristik guru yang kurang baik 
Moderasi Jurnal Studi Ilmu Pengetahuan Sosial, Volume 2, No. 2, h. I6-28

dalam hal ketaatan dan ketepatan masuk pada saat mengajar sehingga mengakibatkan mutu pembelajaran kurang berkualitas.

2. Faktor pendukung dalam hal ini yaitu komunikasi, struktur birokrasi yang menyebabkan Input dan output yang baik sehingga menghasilkan peserta didik yang berkualitas dalam artian memiliki pengetahuan dan keterampilan yang memadai setelah lulus dari Sekolah Menengah Atas Negeri 1 Dolo dan mampu bersaing dengan sekolah lain untuk masuk ke perguruan tinggi.

\section{Kesimpulan dan Saran}

Implementasi kebijakan dari sertifikasi guru yang bertujuan meningkatkan kualitas guru sebagai pendidik dalam segala aspek juga dapat menunjang dan mempengaruhi mutu pembelajaran, sehingga peserta didik yang telah lulus dapat mengembangkan lagi kemampuannya. Keberhasilan guru dalam meningkatkan mutu pembelajaran tidak luput dari komunikasi yang terjalin antara guru dan peserta didik yang berjalan dengan baik dan tata pelaksanaan yang dilakukan oleh guru yang telah tersertifikasi, sehingga menghasilkan peserta didik yang berkualitas, terampil dan memiliki pengetahuan yang baik.

Faktor penghambat dalam penelitian ini yang meliputi implementasi kebijakan sertifikasi guru, yaitu sumber daya, disposisi yang berpengaruh pada proses pembelajaran. Dalam hal ini sikap, sifat atau karakteristik guru yang kurang baik dalam hal ketaatan dan ketepatan masuk pada saat mengajar sehingga mengakibatkan mutu pembelajaran kurang berkualitas yang disebabkan jam masuk belajar yang tidak sesuai dengan yang ditentukan. Serta, faktor pendukung dalam hal ini yaitu komunikasi, struktur birokrasi yang menyebabkan Input dan output yang baik sehingga menghasilkan peserta didik yang berkualitas dalam artian memiliki pengetahuan dan keterampilan yang memadai setelah lulus dari Sekolah Menengah Atas Negeri 1 Dolo dan mampu bersaing dengan sekolah lain untuk masuk ke perguruan tinggi.

Disarankan kepada Kepala Sekolah Menengah Atas Negeri 1 Dolo sebaiknya memberikan teguran kepada guru, baik yang telah tersertifikasi maupun yang belum untuk masuk mengajar tepat waktu. Hal ini tentu saja akan menunjang pembelajaran yang lebih maksimal dan dapat meningkatkan lagi kualitas peserta didik yang lulus dari Sekolah Menengah Atas Negeri 1 Dolo. Dalam hal ini selain menumbuhkan rasa tanggung jawab juga akan membuat peserta didik menjadi disiplin dengan datang tepat waktu dan keluar sesuai dengan waktu yang telah ditetapkan.

\section{Referensi}

Juliartha. 2009. Model Implementasi Kebijakan Publik. Trio Rimba Persada: Jakarta.

Nazir, Moh. 2003. Metode Penelitian. Ghalia Indonesia: Jakarta.

Norliana. 2006. Risk Assessment Process of Hazards in Construction Sites. Faculty of Civil Engineering, University Teknologi Malaysia.

Singarimbun Masrin dan Sofian Effendi. 2006. Metode penelitian survai (Revisi). LP3ES: Jakarta.

Sugiyono. 2001. Statistik nonparametris untuk penelitian. Alfabeta: Bandung. 
Moderasi Jurnal Studi Ilmu Pengetahuan Sosial, Volume 2, No. 2, h. 16-28

Menteri Pendidikan Nasional mengeluarkan peraturan Nomor 18 Tahun 2007 tentang sertifikasi bagi guru 